\title{
TYÖVÄENTUTKIMUKSEN HAASTEET 2020-LUVULLA
}

\author{
Pirjo Markkola \\ professori, Tampereen yliopisto
}

Työväentutkimusta tehdään monilla tieteenaloilla. Sekä sosiaalihistorian valtavirta että yhteiskuntatieteellinen työelämätutkimus voidaan monessa mielessä laskea työväentutkimuksen piiriin. Tässä kirjoituksessa keskityn lähinnä historian ja perinteen tutkimukseen, jota on harjoitettu kohta 40 vuotta Työväen historian ja perinteen tutkimuksen seuran piirissä. Alkuvaiheessa monet mukaan lähteneet tutkijat ja työväenhistorian harrastajat olivat erittäin motivoituneita, ja ideoita riitti. Tiedonnälkä oli suurta, monet tutkimuskysymykset olivat jännittävällä tavalla uusia ja työväentutkimuksen tekeminen historian ja perinteen tutkimuksen piirissä näyttäytyi merkittävänä uutena haasteena.

Nyt 2020-luvulle tultaessa tilanne on muuttunut. Työväen historian ja perinteen tutkimuksen seura on järjestänyt kymmeniä kesäseminaareja ja julkaissut kymmeniä kirjoja, joiden kirjo yltää politiikasta perhe-elämään, työväenliikkeestä työmarkkinoihin ja kulttuurista kokemukseen. Kun lähes kaikkia teemoja on jo käsitelty, yksi työväentutkimuksen keskeisistä haasteista on sen säilyminen kiinnostavana. Miten järjestää seminaareja ja tuottaa julkaisuja, jotka kiinnostavat sekä suurta lukevaa yleisöä että akateemista yhteisöä? Mitä uutta työväentutkimuksella voisi olla sanottavana? Hahmottelen tässä lyhyesti, miten työväentutkimus puolustaa paikkaansa uudella vuosikymmenellä ja vielä sen jälkeenkin.
Kyky uudistua ja samalla muistaa omat juurensa on yksi työväentutkimuksen haasteista 2020-luvulla. Kun työväentutkimuksen harjoittajat avautuvat ajankohtaisille kysymyksille ja kaivelevat niitä hieman pintaa syvemmältä, heillä on paljon sanottavaa tulevaisuudessakin. Maailma on täynnä viheliäisiä ongelmia, kuten ajatuspajojen ja strategiamaakareiden suosima ilmaisu kuuluu.

Ikääntyminen, ilmastonmuutos ja kestävä kehitys ovat myös työväentutkimuksen näkökulmasta ajankohtaisia. Työväentutkijoiden on syytä olla kiinnostuneita ikääntymiseen liittyvistä yhteiskunnallisista ulottuvuuksista. Miten tulotaso- ja toimeentuloerot vaikuttavat ikääntyvän väestön elämään, ja millä tavalla niistä aiheutuvia epäkohtia on mahdollista korjata? Myös ilmastokysymyksen ulottuvuuksista tarvitaan yhteiskuntaa ja ihmisten toimintaa koskevaa uutta tietoa. Mikä voisi olla sosiaalisesti oikeudenmukaista ilmastopolitiikkaa? Miten historiallistaa kestävää kehitystä suhteessa yhteiskunnalliseen oikeudenmukaisuuteen? Onko ilmasto-ongelma eläkeläisen lautasella vai lapsiperheen arjessa?

Toinen ja hieman toisenlainen työväentutkimuksen haaste löytynee tavasta käsitteellistää ruumiin ja mielen yhteyttä ja siihen liittyen yksilöiden kokemusta työstä ja arjesta. Työväentutkimuksen näkökulmasta kiinnostavia ja haastavia teemoja nousi esiin vammaisuuden historiaa käsittelevässä kansainvälisessä konfe- 
renssissa, joka järjestettiin Tampereen yliopistossa elokuussa 2019. Yllättävän monissa esitelmissä keskiöön tuotiin fyysisen ja psyykkisen työkyvyn merkitys vammaisuuden määrittelyssä ja vammaisten omassa eletyssä todellisuudessa. Kyky tehdä työtä ja vaatimus työkyvystä ihmisarvon mittana osoittautuivat yhteisiksi niin itäblokin maiden työnsankari-ihanteille kuin Yhdysvaltain äänioikeuslainsäädännölle.

Kansainvälisen vammaistutkimuksen innoittamana väitän, että esimerkiksi työkyvyn määrittämiseen, vähemmistöjen oikeuksiin, työuupumuksen kokemukseen ja mielenterveyteen liittyvät kysymykset ovat myös työväentutkimuksen haasteita. Näistä tarvitaan lisää historiallista ja ajankohtaista tutkimusta.

Kolmas työväentutkimuksen haaste löytyy tavasta ymmärtää yhteiskunnallisen muutoksen ja poliittisten liikkeiden uudistumista ja uudistamista. Miten tutkijat osaavat lukea poliittisten toimijoiden signaaleja ja antaa keskusteluun oman tutkimuksellisen kontribuutionsa? Tästä voi ottaa esimerkiksi ministeri Sanna Marinin kesällä 2019 esittämän vision neljän päivän työviikosta tai kuuden tunnin työpäivästä. Ajatus työelämän uudistamisesta liittyy jatkuvaan yhteiskunnalliseen muutokseen, jossa työväentutkimuksen edustajat voisivat katsoa ennakkoluulottomasti sekä eteenpäin että taaksepäin. Työväenliike esitti alkuvaiheessa suuria ja mahdottoman tuntuisia vaatimuksia, joiden toteutumisesta meillä on paljon tutkittua tietoa. Visioinnin tunnistaminen ja erittely ei voi jäädä vain työväenliikkeen alkuaikojen historiankirjoitukseksi. Yhteiskunnan muutos tarjoaa työväentutkijoille tärkeitä haasteita.

Neljäs työväentutkimuksen haaste 2020-luvulta löytyy ylirajaisista ilmiöistä ja globaaleista työmarkkinoista, joista on toki puhuttu jo pitkään. On tavallaan ironista, että työväenliike syntyi kansainväliseksi liikkeeksi mutta koteloitui monin paikoin hyvinkin kansalliseksi ilmiöksi, ja tämä koskee myös työväentutkimusta. Varsinkin työväen historian ja perinteen tutkijat ovat monissa maissa keskittyneet oman maansa työväenliikkeen eri fraktioiden kartoittamiseen ja selittämiseen. Yksittäisen maan työväestön olot ovat sosiaalihistoriallisessa tutkimuksessa olleet pitkään kiinnostavampia kuin esimerkiksi ylirajaiset prosessit ja samankaltaisuudet eri työväestöjen kesken. Vaikka kansainvälisestä työväenliikkeestä ja työväestön ylirajaisesta liikkuvuudesta on tehty tutkimusta, tilaa olisi vielä monille uusille avauksille, joissa työväestön globaalit riippuvuudet nousisivat keskiöön. Työväentutkimuksen pitää avata rajoja, ei sulkea niitä. 